УДК: 613.73: 612.1: 796.071

\title{
КОНТРОЛЬ І КОРЕКЦІЯ ТРЕНУВАЛЬНИХ НАВАНТАЖЕНЬ ДЗЮДОЇСТІВ ВИСОКОЇ КВАЛІФІКАЦІЇ З УРАХУВАННЯМ ПОКАЗНИКІВ ЦЕНТРАЛЬНОЇ ГЕМОДИНАМІКИ
}

І. М. Олексенко

Національна медична академія післядипломної освіти імені П. Л. Шупика

Проведено дослідження та аналіз показників центральної гемодинаміки у 15 спортсменів високої кваліфікації, членів збірної команди України з дзюдо, з ознаками перевтоми. Встановлені величини лабораторних показників інтегральної реовазографії, характерних для спортсменів-дзюдоїстів при перевтомі та після корекції тренувального навантаження, на етапі відновлення.

Ключові слова: спортсмени високо кваліфікаці, центральна гемодинаміка, тип кровообігу.

\section{КОНТРОЛЬ И КОРРЕКЦИЯ ТРЕНИРОВОЧНЫХ НАГРУЗОК ДЗЮДОИСТОВ ВЫСОКОЙ КВАЛИФИКАЦИИ С УЧЕТОМ ПОКАЗАТЕЛЕЙ ЦЕНТРАЛЬНОЙ ГЕМОДИНАМИКИ}

\author{
Национальная медицинская академия последипломного образования имени П. Л. Шупика \\ Проведено исследование и анализ показателей центральной гемодинамики у 15 спортсменов высокой квали- \\ фикации, членов сборной команды Украины по дзюдо, с признаками переутомления. Установлены величины \\ лабораторных показателей интегральной реовазографии, характерных для спортсменов-дзюдоистов при пере- \\ утомлении и после коррекции тренировочной нагрузки, на этапе восстановления.
}

Ключевые слова: спортсмены высокой квалификации, экономизация функций аппарата кровообращения, возрастные отличия, стажзанятий.

\section{CONTROL AND CORRECTION OF TRAINING LOADING OF JUDOISTS OF ВИСОКОЙ OF QUALIFICATION TAKING INTO ACCOUNT INDEXES OF CENTRAL HEMODYNAMICS}

\author{
I.M. Oleksenko \\ National Medical Academy of Post-Graduate Education named after P.L. Shupyk
}

\begin{abstract}
A study and analysis of indexes of central hemodynamics are undertaken for 15 sportsmen of high qualification, members of collapsible command of Ukraine on judo, with the signs of overstrain. The sizes of laboratory indexes of integral peовазографии are set, characteristic for sportsmen-judoists at an overstrain and after the correction of the training loading, on the stage of renewal.
\end{abstract}

Key words: sportsmen of high qualification, экономизация of functions of vehicle of circulation of blood, age-related differences, experience of employments.

Вступ. Ефективне управління тренувальним процесом реально при оперуванні достовірною інформацією про стан борця, його тренованість, про результати впливу на нього всіх засобів підготовки. Одержання та аналіз такої інформації і прийняття на її основі управлінських розв'язків - основний зміст прикладного напрямку в медичному забезпеченні підготовки борців.
При тривалій м'язовій роботі настає момент, коли наступає стомлення нервово-м'язового апарата. Якщо говорити про таке складне явище, як перевтома і перетренованість, то цілком очевидно, що це насамперед перевтома нервових центрів. Нервова система атлета розладнується, у силу розбалансування процесів збудження та гальмування [20].

(c) І. М. Олексенко 
В. Л. Карпман і його колеги вважали перетренованість патологічним станом, проявом дезадаптації, порушенням, одержаним в процесі тренування рівня функціональної готовності, регуляції діяльності систем організму, оптимального співвідношення між корою головного мозку і нижчерозміщеними відділами нервової системи, руховим апаратом і внутрішніми органами. В основі перетренованосгі лежить перенапруга коркових процесів, у зв'язку із чим провідними ознаками цього стану є зміни ЦНС, що перебігають за типом неврозів. Більшу роль при цьому відіграють і зміни ендокринної сфери, головним чином кори надниркових залоз й гіпофіза. Крім того, внаслідок порушення регуляції можуть виникати зміни функцій різних органів і систем [12].

Матеріал та методи досліджень. Для обстеження була виділена група спортсменів з ознаками перевтоми, які виражалися різними типами скарг: легка стомлюваність, сонливість, зменшення маси тіла, головні болі, злегка підвищена температура тіла, погіршення здатності виконувати складні рухи, більш повільні й менш точні рухи, нестача сили, порушення плавності рухів, зниження координації, нездатність до розслаблення, зниження витривалості, «забитість» м' язів. Борці зазнавали труднощів у доведенні до кінця звичної тренувальної програми, а також відчували подовження необхідного часу для відновлення.
Аналіз навчально-тренувального процесу підготовки дорослих борців показав, що основний обсяг виконуваної роботи проходить у зоні змішаних аеробноанаеробних навантажень. Значне поширення даного типу тренувальних завдань обумовлено тим, що робота виконується протягом досить тривалого часу на тлі незначного стомлення спортсмена. Впровадження форм контролю тренувальних навантажень, заснованого на строгому обліку різних ознак виконання роботи, дозволить виділити основну спрямованість тренування. Процедура обліку обсягу проробленої роботи конкретної фізіологічної спрямованості полягала у визначенні загального часу виконання основного навантаження.

Отримані результати. Корекція тренувального навантаження спортсменів з ознаками перевтоми проводилася шляхом зменшення обсягу або інтенсивності виконуваної роботи. У спортсменів легкої і середньої вагових категорій зменшувалася інтенсивність виконуваної роботи, а у спортсменів важкої вагової категорії зменшувався обсяг виконуваної роботи. Розрахунки зміни навантаження проводилися згідно з шкалою оцінки фізичних навантажень в умовних одиницях шляхом множення обсягу, вираженого у хвилинах, на бал, відповідний інтенсивності (табл. 1)

Таблиця 1. Шкала оцінки фізичного навантаження в умовних одиницях (за А. А. Новиковим та В. І. Ситником)

\begin{tabular}{|c|c|c|c|}
\hline $\begin{array}{c}\text { Спрямованість } \\
\text { фізичного навантаження }\end{array}$ & $\begin{array}{c}\text { Число серцевих скорочень за } 1 \\
\text { хвилину }\end{array}$ & $\begin{array}{c}\text { Число серцевих } \\
\text { скорочень за } 10 \text { секунд }\end{array}$ & Оцінка \\
\hline \multirow{8}{*}{ Аеробна } & 114 & 19 & 1 \\
\hline & 120 & 20 & 2 \\
\hline & 126 & 21 & 3 \\
\hline & 132 & 22 & 4 \\
\hline & 138 & 23 & 5 \\
\hline & 144 & 24 & 6 \\
\hline & 150 & 25 & 7 \\
\hline & 156 & 26 & 8 \\
\hline \multirow{4}{*}{$\begin{array}{l}\text { Аеробно - } \\
\text { анаеробна }\end{array}$} & 162 & 27 & 10 \\
\hline & 168 & 28 & 12 \\
\hline & 174 & 29 & 14 \\
\hline & 180 & 30 & 17 \\
\hline \multirow{7}{*}{ Анаеробна } & 186 & 31 & 21 \\
\hline & 192 & 32 & 25 \\
\hline & 198 & 33 & 33 \\
\hline & 204 & 34 & 38 \\
\hline & 210 & 35 & 42 \\
\hline & 216 & 36 & 46 \\
\hline & 222 & 37 & 50 \\
\hline
\end{tabular}

Вважали 480 у.о. і менше - малим, 510-750 у.о. середнім, 750-960 у.о. - значним та 960 у.о. і більше - великим навантаженням. Тому спортсменам, які виконували тренувальне навантаження значне за своєю характеристикою, навантаження зменшували до середнього. 
У таблиці 2 представлені показники центральної гемодинаміки в групи спортсменів, у яких зафіксо- вані ознаки перевтоми. Після корекції тренувального навантаження ці показники зазнали значних змін.

Таблиця 2. Показники центральної гемодинаміки в спортсменів з ознаками перетренованості до- і після корекції тренувального режиму $(\mathrm{n}=15)$

\begin{tabular}{|c|c|c|c|}
\hline \multirow{2}{*}{ Показники центральної гемодинаміки } & до корекції & після корекції & \multirow[b]{2}{*}{$\mathrm{P}$} \\
\hline & $\mathrm{M} \pm \mathrm{m}$ & $\mathrm{M} \pm \mathrm{m}$ & \\
\hline частота серцевих скорочень (уд/хв) & $82,80 \pm 9,6$ & $64,75 \pm 9,3$ & 0,02 \\
\hline середній артеріальний тиск (мм.рт.ст.) & $82,36 \pm 7,5$ & $85,41 \pm 7,6$ & 0,79 \\
\hline ударний обсяг кровообігу (мл) & $111,01 \pm 17,1$ & $100,26 \pm 17,3$ & 0,001 \\
\hline хвилинний обсяг кровообігу (мл/хв) & $8786,63 \pm 1345,7$ & $6177,54 \pm 1273,2$ & 0,001 \\
\hline ударний індекс (мл/Mㄱ) & $53,48 \pm 7,4$ & $46,38 \pm 7,1$ & 0,001 \\
\hline серцевий індекс (л/хв/ $\left./ \mathrm{M}_{2}\right)$ & $4,29 \pm 0,6$ & $2,59 \pm 0,5$ & 0,001 \\
\hline індекс хвилинної роботи серця (кг х м/хв/ $\mathrm{M}_{2}$ ) & $5,07 \pm 0,7$ & $2,95 \pm 0,6$ & 0,001 \\
\hline індекс ударної роботи серця (г х м/M $\left.\mathbf{M}_{2}\right)$ & $61,94 \pm 9,6$ & $57,49 \pm 9,2$ & 0,001 \\
\hline питомий периферійний опір судин (дин х с х см-0,5) & $1534,41 \pm 678,1$ & $2584,72 \pm 738,2$ & 0,001 \\
\hline загальний периферійний опір судин (дин х с х см-0,5) & $761,82 \pm 263,2$ & $1010,63 \pm 334,2$ & 0,001 \\
\hline об'ємна швидкість вигнання (мл/с) & $314,43 \pm 45,1$ & $240,60 \pm 43,8$ & 0,001 \\
\hline потужність лівого шлуночка (Вт) & $3,45 \pm 0,6$ & $2,71 \pm 0,5$ & 0,001 \\
\hline витрата енергії на переміщення 1л / хв обсягу крові (Вт/л) & $10,95 \pm 0,7$ & $12,62 \pm 0,8$ & 0,02 \\
\hline
\end{tabular}

Аналізуючи дані таблиці 2, можна зробити надзвичайно важливий для теорії і практики лікарського контролю висновок: перетренування проявляється, насамперед, у зникненні провідної ознаки високої функціональної готовності спортсмена - економізації функцій: вірогідно збільшуються частота серцевих скорочень, хвилинний обсяг кровообігу, ударний індекс, серцевий індекс, об'ємна швидкість вигнання. При цьому зменшується периферійний опір судинного русла. Після корекції тренувального процесу економізація функцій відновлюється, але не повністю. Контроль ступеня відновлення економізації функцій - клінічна ознака готовності до нових, виснажливих тренувальних навантажень.

Таблиця 3. Показники спектрального аналізу серцевого ритму дзюдоїстів 3 появою ознак перетренування до і після корекції тренувального процесу $(\mathrm{n}=15)$

\begin{tabular}{|l|c|c|c|}
\hline \multirow{2}{*}{ Показники спектрального аналізу серцевого ритму } & до корекції & після корекції & \multirow{2}{*}{$\mathrm{P}$} \\
\cline { 2 - 4 } & $\mathrm{M} \pm \mathrm{m}$ & $\mathrm{M} \pm \mathrm{m}$ & 0,048 \\
\hline LF лежачи, $\mathrm{c}_{2}$ & $1685,629 \pm 825,4$ & $1540,686 \pm 811,6$ & 0,007 \\
\hline HF лежачи, $\mathrm{c}_{2}$ & $1290,029 \pm 1128,4$ & $1363,857 \pm 1201,3$ & 0,141 \\
\hline LF/HF лежачи, ум. од. & $1,81 \pm 0,9$ & $1,64 \pm 0,9$ & \\
\hline
\end{tabular}

Перевтому також можна визначити при дослідженні спектрального аналізу серцевого ритму, де переважають центральні механізми вегетативної регуляції. Співвідношення у спортсменів з ознаками перевтоми виходить далеко за межі нормальних значень співвідношення LF/HF -до 1,81 (табл. 3). Це свідчить про істотні зміни в регуляції діяльності серця - перевагу симпатичних впливів на нього. Корекція трену- вального процесу трохи зменшує напругу регуляторних функцій (вірогідно знижується вплив LF - центрального контуру регуляції, а підвищуються значення HF - автономного контуру), але співвідношення LF/HF залишаються досить високими (1,64 ум. од.). Це дає нам можливість зробити висновок, що стан спортсменів покращився, але ознаки перевтоми залишаються.

Таблиця 4. Показники тривалості інтервалу QT у дзюдоїстів, з появою ознак перетренування до і після корекції тренувального процесу $(\mathrm{n}=15)$

\begin{tabular}{|l|c|c|c|}
\hline & до корекції & після корекції & \multirow{2}{*}{$\mathrm{P}$} \\
\cline { 2 - 3 } & $\mathrm{M} \pm \mathrm{m}$ & $\mathrm{M} \pm \mathrm{m}$ & 0,05 \\
\hline Тривалість QT, мс & $427,2 \pm 16,7$ & $396,6 \pm 16,5$ & 0,7 \\
\hline
\end{tabular}


в яких з'явилися ознаки перевтоми (табл. 4). Якщо до корекції величина цього показника складала 427 мс, то після зниження тренувального навантаження - 396 мс.
Про той факт, що подовження інтервалу QT є несприятливою ознакою при оцінці функціонального стану дзюдоїстів, свідчить і його достовірне укорочення при корекції тренувального процесу у борців,

Таблиця 5. Показники автокореляційного аналізу варіативності серцевого ритму дзюдоїстів 3 появою ознак перетренування до і після корекції тренувального процесу $(\mathrm{n}=15)$

\begin{tabular}{|c|c|c|c|}
\hline \multirow{2}{*}{ Показники автокореляційного аналізу серцевого ритму } & До корекції & Після корекції & \multirow{2}{*}{$\mathrm{P}$} \\
\hline & $\mathrm{M} \pm \mathrm{m}$ & $\mathrm{M} \pm \mathrm{m}$ & \\
\hline Мо лежачи, с & $0,9 \pm 0,1$ & $0,95 \pm 0,1$ & 0,6 \\
\hline АМо лежачи, \% & $38,1 \pm 11,4$ & $41,2 \pm 12,1$ & 0,2 \\
\hline MxDMn лежачи, c & $0,4 \pm 0,2$ & $0,3 \pm 0,2$ & 0,2 \\
\hline IH лежачи, $\% / c_{2}$ & $110,4 \pm 79,4$ & $125 \pm 85,3$ & 0,9 \\
\hline
\end{tabular}

Як випливає із даних, представлених у таблиці 5, суб' єктивні ознаки перевтоми не знаходять свого відображення при автокореляційному аналізі серцевого ритму.

У 12 з 15 спортсменів, у яких колись були зареєстровані гіпокінетичний і еукінетичний типи крообігу, 3 появою симптоматики перевтоми, тип кровообігу 3 гіперкінетичного, після корекції фізичних навантажень, став еукінетичним, а з еукінетичного - гіпокі- нетичним, що знайшло своє віддображення в середніх показниках серцевого індексу 4,29 л/хв/м² до корекції стану і 2,59 л/хв/м² після корекції (табл. 2).

Зміни навантаження в тренуваннях дали можливість виключити явища перевтоми та перетренованості у спортсменів та виявити зміни типів кровообігу, які характеризують процеси економізації в роботі організму спортсмена (табл. 6).

Таблиця 6. Зміни типів кровообігу при корекції фізичного навантаження

\begin{tabular}{|l|c|c|c|c|}
\hline \multirow{2}{*}{ Спортсмен } & \multirow{2}{*}{ Стать } & Вагова & \multicolumn{2}{|c|}{ Тип кровообігу } \\
\cline { 4 - 5 } & & категорія & до корекції & після корекції \\
\hline Селезень Д. & чоловіча & важка & Еукінетичний & Гіпокінетичний помірний \\
\hline Гонтюк Р. & чоловіча & середня & Еукінетичний & Еукінетичний 3 тенденцією до гіпо \\
\hline Настуєв М. & чоловіча & легка & Гіперкінетичний & Еукінетичний \\
\hline Мороховець С. & чоловіча & легка & Гіперкінетичний & Гіпокінетичний \\
\hline Ревенко Р. & чоловіча & середня & Еукінетичний & Гіпокінетичний помірний \\
\hline Білодід Г. & чоловіча & середня & Еукінетичний & Гіпокінетичний помірний \\
\hline Машуренко Р. & чоловіча & важка & Гіпокінетичний виражений & Гіпокінетичний різко виражений \\
\hline Русляков В. & чоловіча & важка & Гіпокінетичний & Гіпокінетичний виражений \\
\hline Матросова А. & жіноча & важка & Гіпокінетичний виражений & Гіпокінетичний різко виражений \\
\hline Греков В. & чоловіча & середня & Еукінетичний & Гіпокінетичний \\
\hline
\end{tabular}

Висновок. Отримані результати дозволяють за типом кровообігу, що є індивідуальною характеристикою спортсмена, надавати рекомендації щодо корегування його фізичного стану та оцінювати вплив на організм фізичного навантаження у процесі проведення поточних оглядів, а також використовувати для ранньої діагностики перевтоми та перетренування.

\section{Література}

1. Викулов А. Д. Кровообращение у спортсменов-пловцов /А. Д. Викулов. -Ярославль, 2001. - 115 с.

2. Функциональные резервы сердечно-сосудистой системы и их оценка / Э. А. Городниченко, А. Д. Грицук,

Л. Г. Чалова, Г. В. Петрова // Российский физиологическ журнал им. И. М. Сеченова. - 2004 - Т. 90, № 8 - 429 с.

3. Граевская Н. Д. Спортивная медицина: Курс лекций и практические занятия: учебное пособие / Н. Д. Граевская, Т. И. Долматова. - М.: Советский спорт, 2004. - 304 с.

4. Дембо А. Г. Актуальные проблемы современной спортив- ной медицины / А. Г. Дембо. - М. : ФиС, 1980. - 296 с. 5. Дембо А. Г. О значении исследования сердечного ритма в спортивной медицине / А. Г. Дембо, Э. В. Земцовский // ТиПФК 1980. -№ 3. -13-15 c.

кбйЗемцовский Э.В. Некоторые итоги и перспективы развития учения А. Г. Дембо о дистрофии миокарда у спортсменов/ Э. В. Земцовский // Вестн. спорт, медицины России,- 1995.-№3-4.-С. 10-11.

7. Земцовский Э. В. Спортивная кардиология / Э. В. Земцовский. - СПб., 1995. -448 с. 
8. Динамика кровообращения при минимальных физических нагрузках / Карпман В. Л., Белоцерковский 3. Б., Любина Б. Г. [и. др.] // Физиология человека. - 1994.-Том. 20. -№ 1.-C.84.

9. Остапенко Л. Осторожно-перетренированность /Л. Остапенко //Спортивная жизнь России. - 1987 . -№ 11. - 140 c. 10. Ситдиков Ф. Г. Адаптация сердца мальчиков 10-12 лет, занимающихся борьбой дзюдо, к физической нагрузке различной интенсивности /Ф. Г. Ситдиков, И. Ш. Мутаева // Тезисы V Всероссийского симпозиума и школы-семинара молодых ученых и учителей. -Казань, 2000. - С . 126127.

11. Сердечный выброс, объем сердца и физическая работоспособность юных борцов/С. В. Хрущев, В. Н. Хельбин // Методы исследования и оценки системы кровообращенияу борцов.-М, 1980.-С. 56-57. 